\title{
DIGITALISASI DAN SISTEM OTOMASI PERPUSTAKAAN STIE SYARI'AH BENGKALIS
}

\author{
Decky Hendarsyah \\ Sekolah Tinggi Ilmu Ekonomi (STIE) Syariah Bengkalis \\ Email: deckydb@gmail.com
}

\begin{abstract}
Abstrak
Perpustakaan merupakan gudang ilmu, sebab disanalah terdapat berbagai macam sumber keilmuan yang diabstraksikan dalam baik dalam bentuk gambar maupun tulisan. Perpustakaan sendiri diawali dengan adanya perpustakaan tradisional dimana terdiri dari kumpulan buku-buku tanpa katalog, kemudian berkembang menjadi perpustakaan semi modern yang sudah menggunakan katalog (index). Tetapi perpustakaan semi modern ini jika diterapkan untuk perpustakaan kampus sangat tidak relevan lagi, karena pengelola dan pengguna perpustakaan akan mengalami kesulitan sebab koleksi buku sudah sangat banyak. Kesulitannya dapat digambarkan seperti dalam melakukan pencarian buku menggunakan katalog manual dan sirkulasi dicatat secara manual.

Seiring berjalannya waktu dan perkembangan dunia teknologi informasi maka perpustakaan dituntut untuk menerapkan sistem otomasi perpustakaan supaya dalam pengoperasian perpustakaan dapat dibantu dengan menggunakan teknologi komputer sehingga dapat membantu manajemen operasi, akses dan sirkulasi perpustakaan yang lebih cepat. Tetapi setelah adanya sistem otomasi perpustakaan maka otomatis perpustakaan juga mulai dituntut untuk menerapkan sistem digitalisasi koleksi yang ada sehingga koleksi-koleksi yang ada dapat diakses secara digital dan itu sangat membantu sekali bagi pengguna perpustakaan di era digitalisasi ini. Oleh karena itu penulis perlu membahas mengenai Digitalisasi dan Sistem Otomasi Perpustakaan yang diimplementasikan di STIE Syariah Bengkalis.
\end{abstract}

Kata Kunci: Perpustakaan, Perpustakaan Digital, Otomasi Perpustakaan, Perpustakaan STIE Syariah Bengkalis

\section{A. PENDAHULUAN}

Informasi merupakan hal yang sangat dibutuhkan setiap orang. Informasi adalah hasil dari pengolahan data. Tanpa informasi, maka dunia ini akan terasa hampa dan tidak bermakna. Contoh, orang yang ingin berpergian jauh, baik lewat jalur darat, laut maupun udara setidaknya harus mengetahui sedikit informasi mengenai bagaimana perkiraan cuaca waktu dia akan melakukan perjalanan, supaya perjalanannya bisa lancar sampai ke tujuan. Kemudian contoh lainnya, seseorang ingin mengetahui apa-apa saja yang telah terjadi di luar negeri, maka dia harus melihat atau membaca informasi melalui media televisi atau media cetak. Selain itu, banyak lagi contoh informasi yang menjadi kebutuhan hidup bagi manusia. Sedangkan informasi itu terdiri dari beberapa bentuk media diantaranya:

1. Teks:

Berupa tulisan baik tulisan tangan maupun ketikan. Contohnya: surat kabar/koran, buku, majalah, tabloid, tulisan di Internet dan lain-lain. 
2. Gambar:

Berupa kumpulan pixel/dot/titik sehingga menyerupai suatu objek. Contohnya: Photo, Famplet, Poster, dan lain-lain.

3. Audio:

Berupa suara. Contohnya: Tape, Radio, Radio Online, Telepon/HP.

4. Video:

Berupa film atau gambar bergerak. Contohnya: Televisi, Video Conference, Video Online.

Jadi keempat bentuk yang tersebut di atas merupakan media dasar untuk mendapatkan informasi.

Untuk saat ini, teknologi informasi khususnya untuk penyedia informasi harus menyediakan informasi yang cepat, tepat, akurat dan uptodate kepada pengguna informasi. Perpustakaan sebagai salah satu penyedia informasi keberadaannya sangat penting dan dibutuhkan di dunia informasi. Untuk itu, perpustakaan harus mempersiapkan sistem yang baik untuk mengolah dan menyediakan informasi dalam bentuk digital. Salah satunya dengan mewujudkan Digitalisasi dan Sistem Otomasi Perpustakaan STIE Syariah Bengkalis yang terkoneksi dalam jaringan komputer dan Internet.

\section{B. DIGITALISASI PERPUSTAKAAN}

Digitalisasi saat ini sudah banyak dilakukan oleh para pengembang IT (Information Technology) hampir di seluruh belahan dunia. Mulai dari buku, artikel, jurnal, gambar, rekaman suara, rekaman film, surat kabar dan sebagainya sudah didigitalkan. Begitu juga di perpustakaan, digitalisasi koleksi-koleksi yang ada sudah dilakukan secara berangsurangsur sampai semua koleksi yang ada menjadi koleksi digital, sehingga diberi nama perpustakaan digital.

\section{Definisi Perpustakaan Digital (Digital Library)}

The Digital Library Federation mendefinisikan sebagai berikut ${ }^{1}$ :

"Organizations that provide the resources, including the specialized staff, to select, structure, offer intellectual access to, interpret, distribute, preserve the integrity of, and ensure the persistence over time of collections of digital works so that they are readily and economically available for use by a defined community or set of communities" (Walters 1998).

T.B. Rajashekar mendefinisikan sebagai berikut ${ }^{2}$ :

"a managed collection of information, with associated services, where the information is stored in digital formats and accessible over a network".

John Millard mendefinisikan sebagai berikut ${ }^{3}$ :

"Libraries that are distinguished from information retrieval systems because they include more type of media, provide additional functionally and services, and include other stages of the information life cycle, from creation through use. Digital libraries can be viewed as

\footnotetext{
${ }^{1}$ Bambang Setiarso, 2006, "Roadmap Perpustakaan Digital Iptek", dalam ilmukomputer.org 27 September 2006 dengan alamat web http://www.ilmukomputer.org/wp-content/uploads/2006/09/bse-roadmapdliptek.pdf. Diakses tanggal 20 Juni 2013.

${ }^{2}$ Ibid.

${ }^{3}$ Ibid.
} 
a new form of information institution or as an extension of services libraries currently provide".

Digital Library $(D L)$ atau perpustakaan digital adalah suatu perpustakaan yang dapat menyimpan data baik itu buku (tulisan), gambar, suara dalam bentuk file elektronik dan mendistribusikannya dengan menggunakan protokol elektronik melalui jaringan komputer. Istilah Digital Library sendiri mengandung pengertian sama dengan electronic library dan virtual library. Sedangkan istilah yang sering digunakan dewasa ini adalah Digital Library $(D L)$, hal ini bisa kita lihat dengan sering munculnya istilah tersebut dalam workshop, simposium atau konferensi dengan memakai nama tersebut. ${ }^{4}$

Penelitian $D L$ mulai berkembang pesat sejak tahun 1990 diiringi dengan kemajuan teknologi jaringan komputer yang memungkinkan pengaksesan informasi dari satu tempat ke tempat lain yang sangat jauh dalam waktu singkat. Dimulai dengan terselenggarakannya Workshop on Digital Libraries pada tahun 1994, beberapa konferensi lain seperti Digital Libraries $(D L)$ yang disponsori oleh $A C M$, kemudian Advances in Digital Libraries $(A D L)$ yang disponsori oleh IEEE/NASA/NLM, secara berkelanjutan diselenggarakan. Maraknya workshop, simposium, atau konferensi disini membuktikan bahwa semakin banyaknya peneliti yang mulai menggeluti bidang $D L$ ini.

Proyek penelitian $D L$ pada intinya meneliti bidang pendigitalan dokumen dan pembangunan sistem untuk dokumen digital. Pada pendigitalan dokumen, diteliti tentang bagaimana mendigitalkan dokumen dan jenis penyimpanan digital dokumen baik berupa full text maupun page image. Sedangkan bidang pembangunan sistem pada $D L$, diteliti tentang pendesainan dan implementasi sistem untuk memanipulasi data pada database, misalnya penelitian arsitektur sistem yang baik untuk $D L$, baik yang sederhana hingga implementasi teknologi agent dari Artificial Intelligence(AI), dan sebagainya.

Penelitian $D L$ berikutnya adalah tentang hak cipta dari dokumen, payment system, customer system dan aplikasi-aplikasi lainnya. Semua aplikasi yang diteliti diarahkan menuju manajemen aplikasi berbasis elektronik. Misalnya pada penelitian hak cipta dari dokumen, penelitian diarahkan untuk mengembangkan manajemen hak cipta secara elektronik, meskipun tentu saja masih terdapat hambatan terutama pada peraturan hak cipta yang ada.

\section{Penelitian Digital Library $(D L)$ Di Amerika Dan Jepang ${ }^{5}$}

\section{a. TULIP Project}

Pada tahun 1991, delapan universitas yaitu: Carnegie Mellon University, Cornell University, Georgia Institute of Technology, Massachusetts Institute of Technology, University of California, University of Tennesee, University of Washington, Virginia Polytechnic and State University, bersama perusahaan Elsevier Science mengadakan kesepakatan kerjasama penelitian tentang $D L$ yang kemudian terkenal dengan nama TULIP (The University Licensing Project).

Proyek TULIP ini adalah mendigitalkan data, dokumen, majalah di bidang Material Science. Tema penelitian utama di proyek TULIP ini adalah sebagai berikut:

- Sistem pengumpulan dan penyimpanan data

\footnotetext{
${ }^{4}$ Tabata Kouchi, 1996, “What is Digital Library”, dalam IPSJ Journal Vol. 37 No. 9 1996, Japan, (Japanese).

${ }^{5}$ Romi SatriaWahono, "Menggunakan Mesin Pencari Google dengan kata kunci Proyek Digital Library" dalam artikel "Menengok Proyek Digital Library" dengan alamat web

http://elearning.unej.ac.id/courses/IKC20042/document/pdf01/romi-dl.pdf?cidReq=IKC20042. Diakses Tanggal 20 Juni 2013
} 
- Jenis data yang disimpan

- Promosi dari proyek TULIP

- Sistem penarikan biaya dari penggunaan $D L$

- Teknik pengaksesan $D L$

\section{b. NSF/ARPA/NASA Project}

Pada bulan September 1995, NSF/ARPA/NASA mengeluarkan dana sekitar 25 juta US dolar untuk membiayai enam proyek penelitian $D L$. Masing-masing proyek penelitian dipusatkan di enam universitas dengan proyek penelitian sebagai berikut:
a. Carnegie Mellon University: Informedia Interactive Online Video Digital Library
b. University of Michigan: The University of Michigan Digital Library (UMDL)
c. University of Illinois at Havana: Interspace
d. University of California at Barkeley: Electronic Enviromental Library
e. Stanford University: Stanford Integrated Digital Library Project
f. University of California at Santa Barbara: Alexandria Digital Library

Proyek penelitian $D L$ dari NSF/ARPA/NASA tersebut boleh dibilang sebagai proyek penelitian yang cukup berhasil dan menjadi dasar penelitian-penelitian $D L$ di dunia. Hal ini karena didukung oleh peneliti-peneliti di berbagai bidang, organisasi penerbit dan percetakan, perpustakaan-perpustakaan dan juga pemerintah Amerika sendiri.

\section{c. National Digital Library Project}

Perpustakaan nasional seperti kita ketahui adalah perpustakaan dengan dokumen yang terlengkap pada suatu negara dan biasanya menyimpan dokumen-dokumen yang sangat penting. Untuk kelancaran distribusi dokumen dan menjaga keawetan dokumen, dimulailah usaha dan penelitian untuk mendigitalkannya. Tidak hanya di Amerika, di beberapa negara-negara maju misalnya Perancis, Jepang dan sebagainya usaha membangun $D L$ untuk perpustakaan nasional juga sudah dimulai.

\section{d. NACSIS-ELS}

Proyek dikoordinasi oleh MONBUSHO dan diberi nama NACSIS-ELS (National Center for Science Information Systems-Electronic Library Sistem). Data yang disimpan berupa jurnal penelitian, majalah ilmiah, dan data-data yang berhubungan dengan penelitian ilmiah lainnya. Transfer data menggunakan protokol yang merupakan pengembangan dari ANSI Z 39.50, dan software browser menggunakan software browser khusus yang diproduksi sendiri oleh proyek NACSIS-ELS yang dibagikan secara gratis. Masalah yang mendasar pada penelitian NACSIS-ELS adalah sistem penyimpanan data yang menggunakan page image, untuk itu penelitian dilanjutkan dengan tema merubah data page image ke data full text.

\section{Hak Cipta Dokumen}

Hak cipta terbagi atas dua: ${ }^{6}$

1. Hak cipta pada dokumen yang didigitalkan.

Yang termasuk didalamnya adalah: merubah dokumen ke digital dokumen, memasukkan digital dokumen ke database, merubah digital dokumen ke hypertext dokumen.

\footnotetext{
${ }^{6}$ Nawa Kotaro, 1996, "Digital Library and Copyright”, di dalam IPJS Journal Vol. 37 No. 9 1996, Japan. (Japanese).
} 
2. Hak cipta pada dokumen di communication network.

Didalam hukum hak cipta masalah transfer dokumen lewat komputer network belum didefinisikan dengan jelas. Hal yang perlu disempurnakan adalah tentang: hak menyebarkan, hak meminjamkan, hak memperbanyak, hak menyalurkan baik kepada masyarakat umum atau pribadi, semuanya dengan media jaringan komputer termasuk didalamnya intranet, internet dan sebagainya.

Pengaturan hak cipta pada digital dokumen diatas sangat diperlukan terutama untuk memperlancar proyek $D L$ di dunia. Salah satu wujud nyata adalah penelitian tentang ECSM (Electronic Copyright Management System), yang intinya adalah sistem yang memonitor penggunaan digital dokumen oleh user secara otomatis.

\section{Pengembangan Digital Library $(D L)^{7}$ :}

Pengembangan $D L$ juga perlu diperhatikan beberapa kendala adalah sebagai berikut:

a. Pencarian online, perlu mengetahui prinsip-prinsip ICT (Information Communication and Technology), strategi penelusuran online, kemampuan (jam terbang) menelusur online, kalau tidak akan mendapatkan informasi yang dihendaki;

b. Terlalu besarnya sumber informasi dan pengetahuan dalam bentuk digital, maka searching tidak dapat menghasilkan hits file yang sesuai dengan topik, atau informasi/pengetahuan yang mendalam;

c. Perbedaan sistem pada sistem pencarian secara online, seperti untuk e-journal berbeda dengan web search tools atau dengan Digital Library dimana berbeda search interfaces atau sering digunakan search syntax yang beda, membuat harus mengenal semua search tools yang ada dulu;

d. Mengenal dulu topik yang akan dicari dan struktur $D L$, mengenal pengorganisasian content dari berbagai sistem seperti: e-jurnal, online databases, $D L$ dan sebagainya;

e. Sulit memutuskan bagi pemakai dari sejumlah meta-database berdasarkan subjek/topik, sehingga yang mana akan dipilih dari berbagai $e$-jurnal dan berbagai database;

f. Sering dari online-database hanya abstraknya saja, dan ada prosedur/search lain untuk memperoleh full-textnya;

g. Pemakai juga sering dibikin pusing oleh search option seperti: kata kunci, subjek, judul, atau kata kunci subjek dan sulit dibedakan bagi pemakai;

h. Online dengan bandwidth rendah, makan waktu, membuat frustasi, untuk download makan waktu yang panjang dan kadang-kadang putus di tengah jalan;

i. Kadang-kadang prosedur search terlalu rumit dan panjang sehingga makan waktu yang panjang hanya untuk mencari misalnya fulltext journal articles, kesulitan untuk memutuskan yang mana relevan dengan yang dicari;

j. Pengorganisasian informasi di $D L$, kalau terlalu spesifik punya dampak dalam pemilihan oleh pemakai, atau kadang-kadang tidak terlihat dilayar utama, tapi tersembunyi di layar berikutnya, sehingga pemakai harus menjelajah webpage untuk mendapatkan berbagai macam sumber informasi yang tersedia.

Intinya pemakai menginginkan "A One-Stop Window Search" ini yang menjadi persoalan pustakawan untuk mendisian $D L$ yang terdiri dari berbagai sistem operasi, perangkat lunak, perangkat keras, search engine, interface dsb.

\footnotetext{
${ }^{7}$ Ibid.
} 
Kemungkinan pemecahan yang dapat dilakukan:

a. Implikasi dari $D L$ harus ada pelatihan mengenai struktur $D B$, meta database atau data mining yang kita pakai, strategi penelusuran dan teknik penelusuran secara online, dan seterusnya;

b. Artinya pemakai harus mempersiapkan dan meluangkan waktu untuk mencari informasi/pengetahuan yang sesuai dengan sistem atau karakter dari search engine, database, atau sistem operasinya, setelah itu baru ditekankan pada kurikulum pelatihannya, juga perlu dipikirkan adalah disain database dan struktur databasenya;

c. Pendekatan A One-Stop Window dimana pemakai dapat melihat dan menggunakan satu interface search untuk mencari informasi dari berbagai macam sistem, databases, dan seterusnya;

d. Konsekuensi pendekatan A One-Stop Window adalah harus lengkap panduan "online help" untuk membimbing/ atau petunjuk bagi pemakai secara lengkap;

e. Terkait dengan kesenjangan digital, maka data statistik pemakai perlu dilengkapi: berapa pemakai yang terkoneksi ke internet, berapa pemakai yang akan akses ke $D L$, siapa yang sering menggunakan $D L$ ?, berapa pemakai yang menggunakan koneksi ke internet dengan a high bandwidth connection?;

f. Sistem akses informasi harus didisain untuk dimungkinkan akses ke sumbersumber informasi di $D L$, intranet dan internet dari suatu institusi;

g. Pada umumnya pemakai tidak mau banyak meluangkan waktu selain search, jadi mekanisme automatic filtration harus berdasarkan karakter pemakai, tugas pemakai, atau pilihan pemakai;

h. Fasilitas untuk menggunakan "search term dictionary atau vocabulary control tools adalah sangat mutlak untuk good DL search interfaces.

\section{Pengolahan Dokumen Elektronik (Digitalisasi Dokumen)}

Pengelolaan dokumen elektronik memerlukan teknik khusus yang memiliki perbedaan dengan pengelolaan dokumen tercetak. Proses pengelolaan dokumen elektronik melewati beberapa tahapan, yang dapat kita rangkumkan dalam proses digitalisasi, penyimpanan dan pengaksesan kembali dokumen. Pengelolaan dokumen elektronik yang baik dan terstruktur adalah bekal penting dalam pembangunan sistem perpustakaan digital (Digital Library) ${ }^{8}$.

\section{a. Proses Digitalisasi Dokumen}

Proses perubahan dari dokumen tercetak (printed document/hardcopy) menjadi dokumen elektronik sering disebut dengan proses digitalisasi dokumen. Seperti pada Gambar 1, dokumen mentah (jurnal, prosiding, buku, majalah, tabloid, koran dsb.) diproses (di-scan) dengan sebuah alat yang bernama scanner untuk menghasilkan dokumen elektronik (softcopy) $)^{9}$. Proses digitalisasi dokumen ini tentu tidak diperlukan lagi apabila dokumen elektronik sudah menjadi standar dalam proses dokumentasi sebuah organisasi.

\footnotetext{
${ }^{8}$ Romi Satria Wahono, 1998, “Digital Library: Chalenges and Roles Toward $21^{\text {th }}$ Century”, dalam Proceedings of Tekno '98 Symposium, Nagaoka, Japan.

9 Yudha Yudhanto, 2008, "Menggagas Perpustakaan Digital”, dalam ilmukomputer.org 28 November 2008 dengan alamat web http://ilmukomputer.org/2008/11/28/menggagas-perpustakaan-digital/, Diakses tanggal 21 Juni 2013.
} 


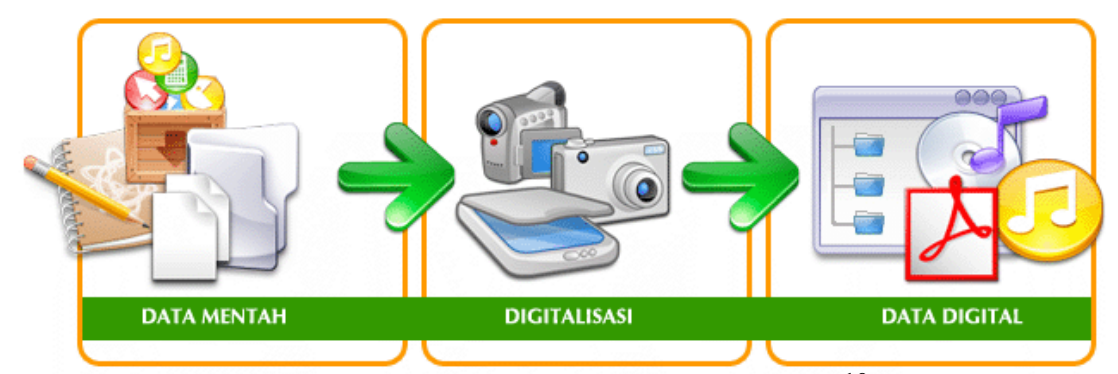

Gambar 1. Digitalisasi Dokumen ${ }^{10}$

\section{b. Proses Penyimpanan Dokumen Elektronik}

Pada tahap ini dapat dilakukan pemasukan data (data entry) dan perubahan data (editing). Data yang akan disimpan terdiri dari beberapa item/field seperti kode, nomor klasifikasi, judul, pengarang, penerbit, tahun terbit, kota terbit, deskripsi fisik, abstrak, isi dan sebagainya. Klasifikasi pustaka di Indonesia sering menggunakan UDC (Universal Decimal Classification) atau DDC (Dewey Decimal Classification $)^{11}$.

Ada dua pendekatan dalam proses penyimpanan, yaitu pendekatan basis file (file base approach) dan pendekatan basis data (database approach). ${ }^{12}$ Masing-masing pendekatan memiliki kelebihan dan kelemahan (Tabel 1), dan pendekatan dapat dipilih berdasarkan kebutuhan.

Tabel 1. Perbedaan Antara File Base Approach dan DatabaseApproach

\begin{tabular}{|l|l|}
\hline File Base Approach & Database Approach \\
\hline Data duplication & Data sharing and no duplication \\
\hline Data dependence & Data independence \\
\hline Incompatible file format & Compatible file format \\
\hline Simple & Complex \\
\hline
\end{tabular}

\section{c. Proses Pengaksesan dan Pencarian Kembali Dokumen}

Untuk melakukan proses pengaksesan dan pencarian kembali dokumen tergantung kepada aplikasi yang digunakan. Jika aplikasi database-nya bagus dan fleksibel maka pengaksesan dan pencarian dokumen akan cepat, tepat dan akurat. Sehingga memudahkan pengguna dalam mendapatkan dokumen yang dicari. Tetapi sebaliknya jika aplikasi dan database yang digunakan tidak bagus dan terbatas kemampuannya dalam penyimpanan dokumen, maka akan memperlambat pengaksesan dan pencarian dokumen.

Jadi intinya dari proses ini adalah bagaimana kita dapat melakukan pencarian kembali terhadap dokumen yang telah kita simpan dengan cepat, tepat dan akurat. Metode pengaksesan dan pencarian kembali dokumen akan mengikuti pendekatan proses penyimpanan yang kita pilih. Pendekatan database membuat proses ini lebih fleksibel dan efektif dilakukan, terutama untuk penyimpanan data skala besar. Di sisi lain, kelemahannya adalah relatif lebih rumitnya sistem dan proses yang harus kita lakukan.

\footnotetext{
${ }^{10} \mathrm{Ibid}$.

${ }^{11}$ Ibid.

${ }^{12}$ Connolly, T.M., and Begg C.E., 2002, "Database Systems: A Practical Approach to Design, Implementation, and Management ( $3^{\text {rd }}$ edition)", Boston, Addison Wesley.
} 
Menariknya, karena sifat pendekatan database yang memiliki kebebasan terhadap data (data independence), dengan data yang sama kita bisa membuat interface ke berbagai aplikasi lain baik yang berbasis standalone maupun web.

\section{DIGITALISASI PERPUSTAKAAN STIE SYARIAH BENGKALIS}

Perpustakaan STIE Syariah Bengkalis telah mendigitalkan data-data penting dari buku seperti judul, pengarang, penerbit dan lain-lain. Kemudian juga sudah mendigitalkan cover, abstrak, rangkuman, deskripsi dan daftar isi dari buku serta skripsi mahasiswa. Dimana proses pendigitalan abstrak, rangkuman, deskripsi dan daftar isi buku dilakukan dengan cara diketik. Sedangkan cover buku didigitalkan dengan cara discan. Skripsi mahasiswa didigitalkan oleh mahasiswa sendiri dengan cara diketik dan menyerahkan file digital skripsi kepada petugas perpustakaan STIE Syariah Bengkalis. Untuk penyimpanan datadata perpustakaan seperti buku, peminjam, skripsi dan lain-lain, perpustakaan STIE Syariah Bengkalis sudah memiliki database yang tersimpan di server yang terintegrasi dengan jaringan komputer sehingga bisa diakses oleh komputer client yang berada diruangan perpustakaan. Kemudian data-data yang tersimpan di server tersebut juga disimpan secara terpisah di database website perpustakaan STIE Syariah Bengkalis yang bisa diakses secara online melalui Internet (Gambar 2).

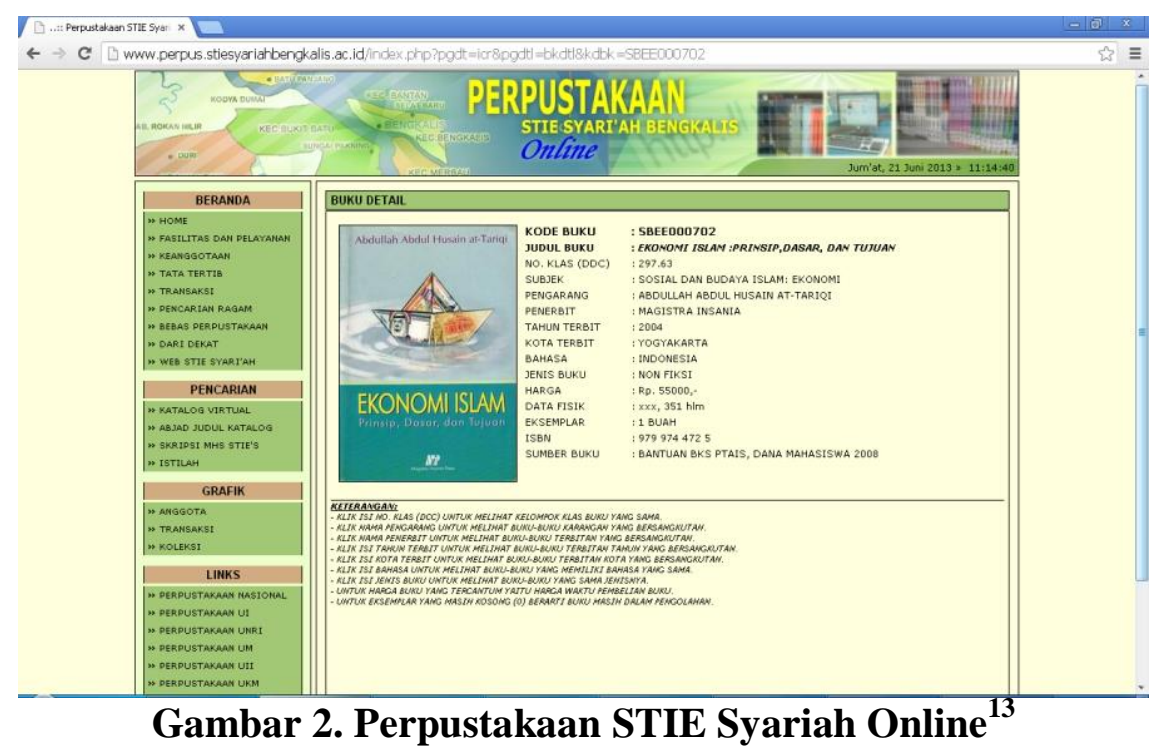

\section{SISTEM OTOMASI PERPUSTAKAAN STIE SYARIAH BENGKALIS}

Sistem otomasi perpustakaan merupakan suatu manajemen sistem yang dapat mempermudah akses baik pengelola maupun pengguna perpustakaan. Sistem otomasi perpustakaan yang baik adalah sistem yang terintegrasi, mulai dari sistem pengadaan bahan pustaka, pengolahan bahan pustaka, sistem pencarian kembali bahan pustaka, sistem sirkulasi (peminjaman, pengembalian dan perpanjangan peminjaman), keanggotaan (membership), pengaturan hak akses keanggotaan, pengaturan denda keterlambatan pengembalian, sistem booking dan sistem reporting aktifitas perpustakaan dengan berbagai

\footnotetext{
${ }^{13}$ http://www.perpus.stiesyariahbengkalis.ac.id/. Diakses tanggal 21 Juni 2013
} 
parameter pilihan. Lebih sempurna lagi, apabila sistem otomasi perpustakaan dilengkapi dengan barcoding dan mekanisme pengaksesan data berbasis web dan internet.

Berikut ini adalah Sistem Otomasi Perpustakaan STIE Syariah Bengkalis yang telah penulis buat dan implementasikan pada Perpustakaan STIE Syari'ah Bengkalis yang diberi nama "Sistem Informasi dan Automasi Perpustakaan (SIAP) STIE Syariah Bengkalis". Dimana fitur-fitur dalam sistem otomasi perpustakaan ini dapat mengakomodasi kebutuhan perpustakaan secara lengkap baik dari pengadaan, pengolahan, penelusuran, manajemen anggota, manajemen pengunjung, booking, dan sirkulasi serta pengolahan dan penelusuran data skripsi mahasiswa, kemudian juga dilengkapi dengan penelusuran istilah/kamus.

\section{Login Sistem}

Sistem ini merupakan sistem multiuser sehingga bisa diakses oleh banyak pengguna/user. Sehingga ketika pertama kali sistem diakses maka sistem akan meminta pengguna untuk memasukkan user ID dan password sebagai otentikasi user seperti Gambar 3. Kemudian sistem akan mengecek user ID dan password yang dimasukkan pengguna sesuai dengan apa yang tersimpan dalam database. Pada sistem ini password telah menggunakan sistem enkripsi sehingga sistem lebih sulit untuk dibobol oleh pihak yang tidak berwenang. Setelah user ID dan password ditemukan maka sistem akan mengatur hak akses dari user tersebut. Sedangkan untuk pengguna sistem yang tidak memiliki user ID diberi hak hanya untuk melakukan pencarian/penelusuran untuk komputer yang diposisikan pada ruang akses atau ruang baca.

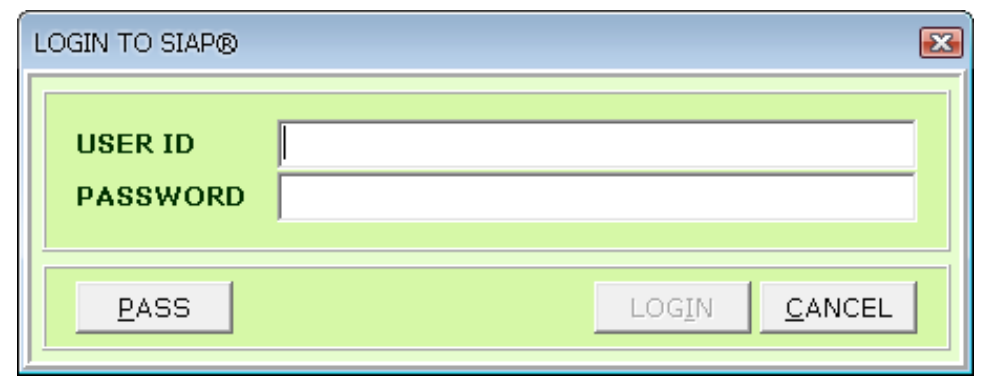

Gambar 3. Login Sistem

\section{Menu Utama}

Menu utama dari sistem ada File, Transaksi, Pencarian, Utility dan Help. Pada menu utama ini juga terdapat sub menu dari masing-masing menu yang ada sesuai dengan fungsi dan tujuannya (Gambar 4). Untuk mengakses menu tiap-tiap tingkatan user akan berbeda hak aksesnya, tergantung hak akses yang telah diatur oleh superuser serta lokasi atau posisi komputer pada perpustakaan. 


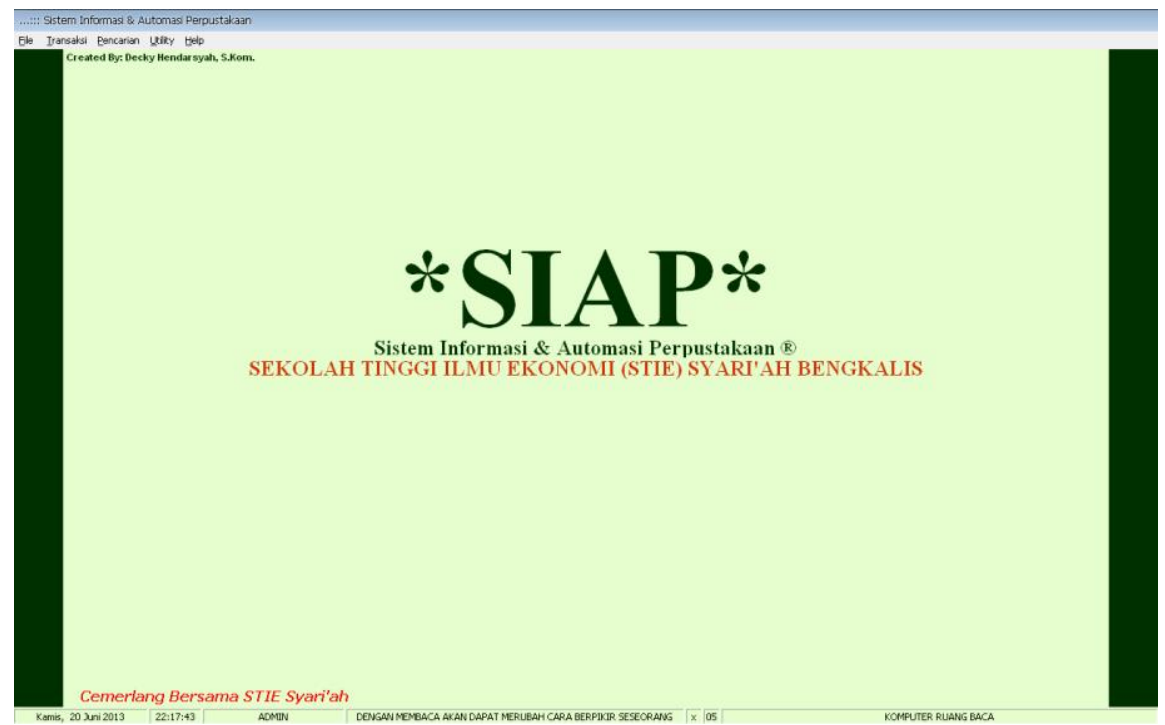

Gambar 4. Menu Utama

\section{Pengolahan User}

Untuk fitur ini diaktifkan melalui menu File > Peminjam yang berfungsi untuk mengatur registrasi data pribadi user, tingkatan user, password yang di enkripsi dan diberi masa aktif user (Gambar 5). Kemudian juga terdapat dalam sub menu Peminjam ini pencarian user, daftar ulang, reporting dan grafik user. Untuk mengakses pengolahan user tidak semua user bisa memakainya. Hanya user operator, supervisor dan super-user yang bisa mengakses. Sedangkan user lainnya tidak diberi hak untuk mengakses fitur ini. Untuk supervisor dan operator hanya bisa membuat account user dengan tingkatan dibawahnya. Operator account-nya dibuat oleh supervisor, sedangkan supervisor account-nya dibuatkan oleh superuser.

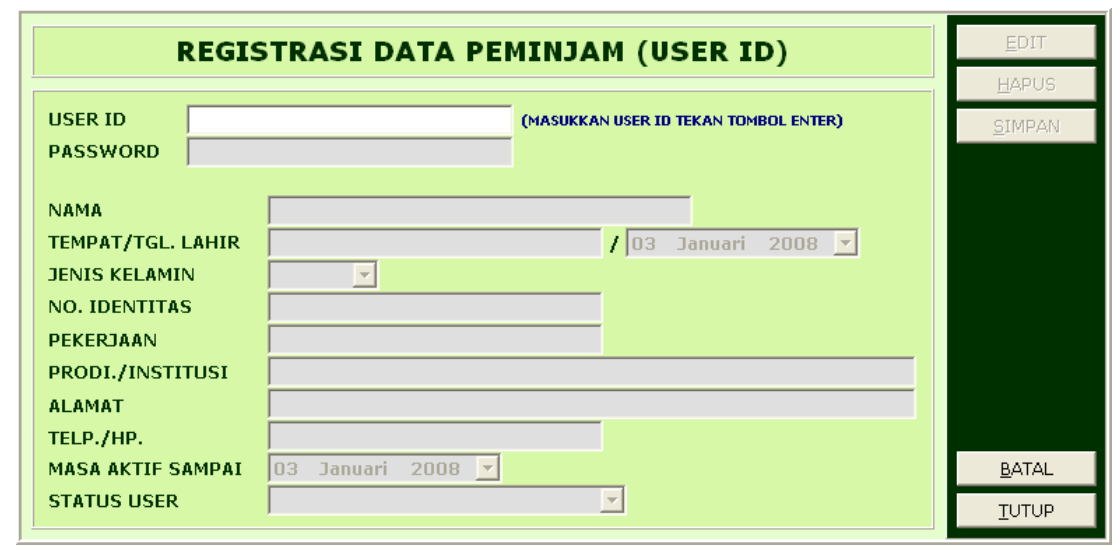

Gambar 5. Pengolahan User

\section{Pengolahan Klasifikasi}

Pada sistem otomasi ini menggunakan klasifikasi DDC (Dewey Decimal Clasification). Fitur ini dapat digunakan sebagai master, pencarian dan reporting klasifikasi. Pada klasifikasi ini selain field nomor klas dan subjek terdapat field kode untuk membantu pengkodean buku. 


\section{Pengolahan Buku}

Fitur ini diaktifkan menu File > Buku yang berfungsi sebagai pengolahan buku (Gambar 6), pemasukkan isi buku, pencarian buku, reporting dan grafik buku. Untuk isi buku sampai saat sekarang pihak pengelola perpustakaan STIE Syari'ah Bengkalis masih belum bisa didigitalisikan karena masih terkendala dengan masalah hak cipta. Tetapi sistem ini sudah dapat digunakan untuk menampilkan isi buku dalam bentuk full text. Isi buku yang hanya bisa dimasukan untuk sekarang hanya abstrak, rangkuman, deskripsi dan daftar isi.

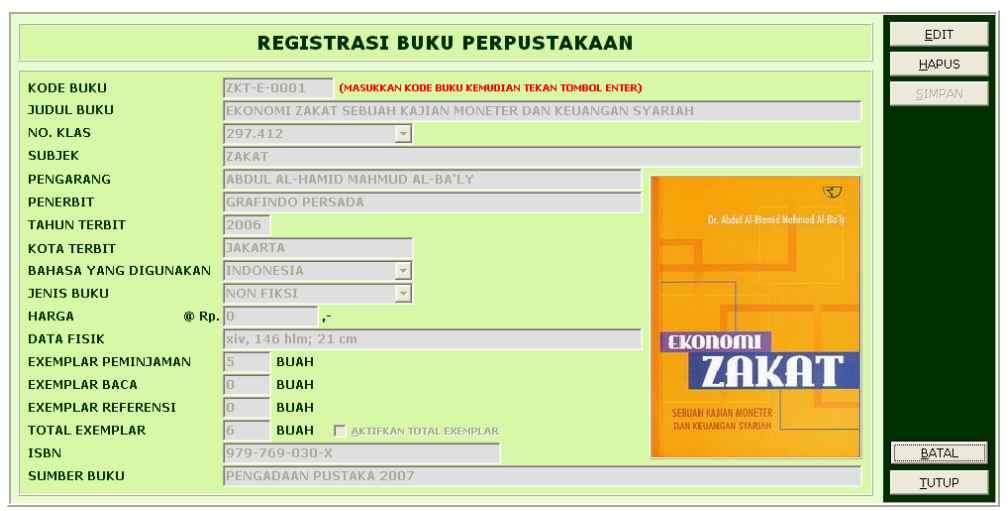

Gambar 6. Registrasi Buku

\section{Pengolahan Skripsi Mahasiswa}

Fitur ini diaktifkan melalui menu File > Skripsi yang berfungsi sebagai pengolahan data skripsi, pemasukkan isi skripsi, pencarian skripsi, reporting dan grafik skripsi. Untuk isi skripsi nantinya pihak pengelola Perpustakaan STIE Syari'ah Bengkalis hanya memasukan abstrak dan daftar isi. Tetapi sistem ini sudah dapat digunakan untuk menampilkan isi skripsi sama seperti buku dalam bentuk full text.

\section{Pengunjung}

Fitur ini diaktifkan melalui menu File $>$ Pengunjung yang berfungsi sebagai pemasukan data pengunjung, pencarian pengunjung, reporting pengunjung dan grafik pengunjung.

\section{Pengolahan Istilah/Kamus}

Fitur ini diaktifkan melalui menu File > Definisi/Kamus yang berfungsi untuk memasukkan istilah-istilah serta kamus seperti istilah-istilah komputer, ekonomi islam dan lain-lainnya yang diambil dari berbagai sumber informasi (Gambar 13).

\section{Sirkulasi/Transaksi}

Fitur ini diaktifkan melalui menu Transaksi yang berfungsi sebagai pengolahan sirkulasi yaitu peminjaman (Gambar 7), pengembalian (Gambar 8), perpanjangan (Gambar 
9) dan booking buku (Gambar 10). Dimana untuk sirkulasi/transaksi ini sewaktu memasukkan user id akan terpampang foto user yang bersangkutan. Kemudian jika memasukkan atau memilih buku yang akan dipinjam, dikembalikan atau diperpanjang masa peminjamannya serta booking buku maka cover buku yang bersangkutan akan ditampilkan pada sistem ini.

Sedangkan untuk denda keterlambatan akan tampil jika tanggal pengembalian melewati tanggal waktu pengembalian sesuai denda dan lama peminjaman yang telah diset oleh superuser. Kemudian jika jumlah peminjaman buku melebihi dari jumlah yang telah diset oleh superuser maka akan muncul komentar "tidak bisa lagi meminjam buku karena sudah melebihi peminjaman”. Untuk booking buku hanya bisa dilakukan jika user login kesistem. Buku hanya bisa di-booking jika buku masih tinggal 1 buah di rak atau sudah habis terpinjam, jadi seorang user bisa mem-booking buku yang telah dipinjam oleh user lain.

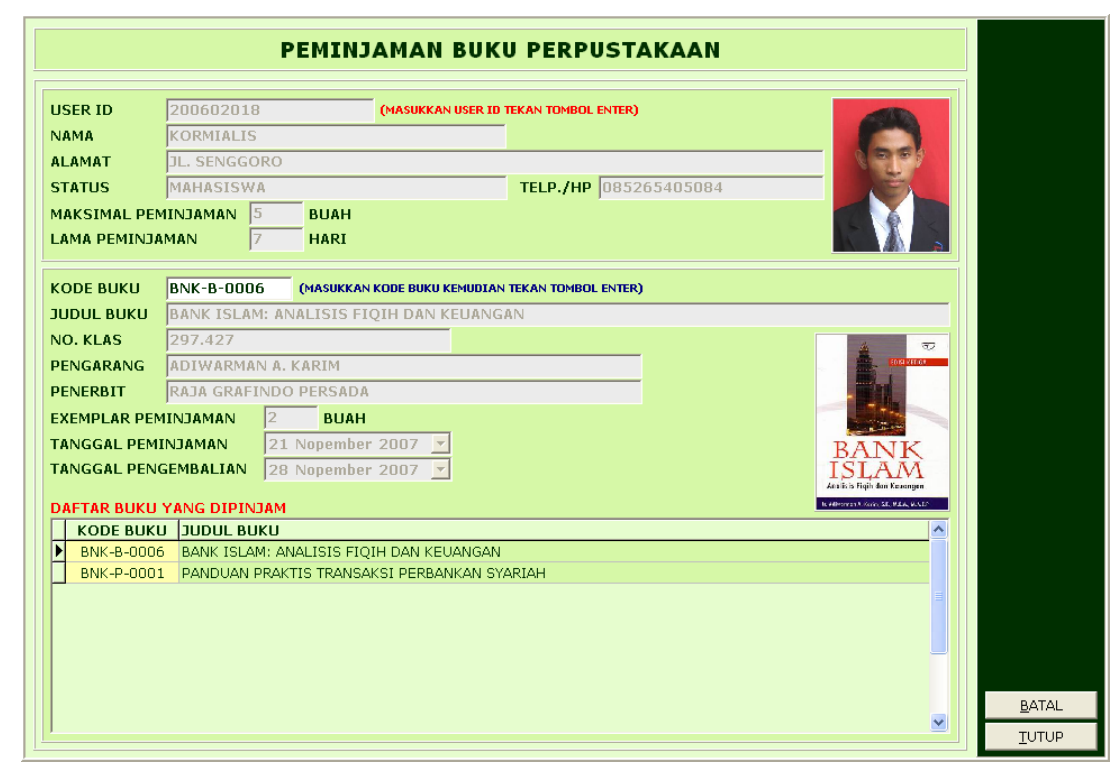

Gambar 7. Fitur Peminjaman Buku

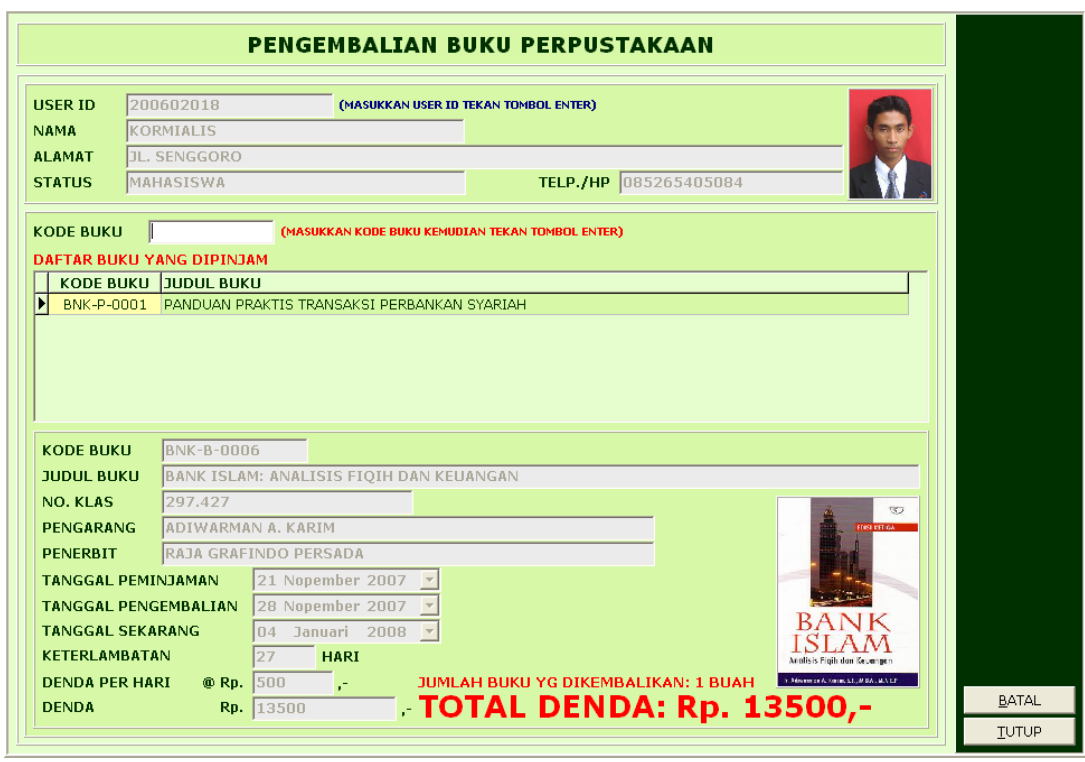

Gambar 8. Fitur Pengembalian Buku 


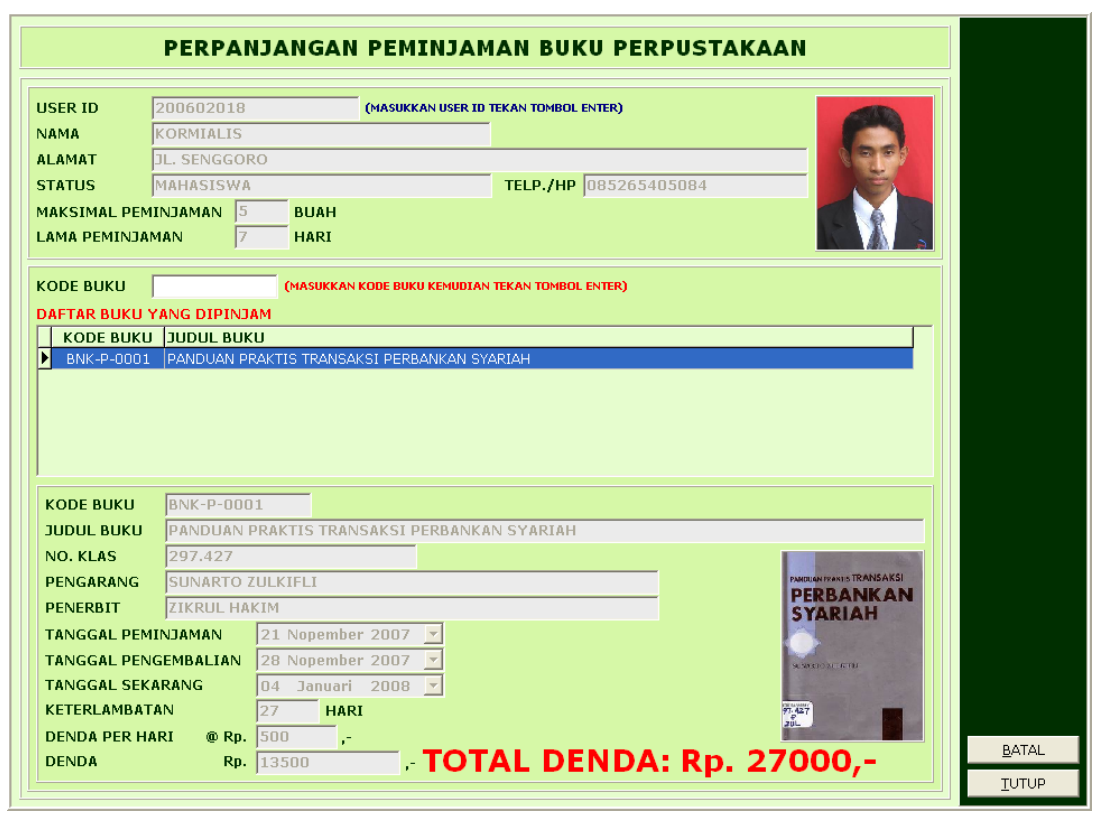

\section{Gambar 9. Fitur Perpanjangan Buku}

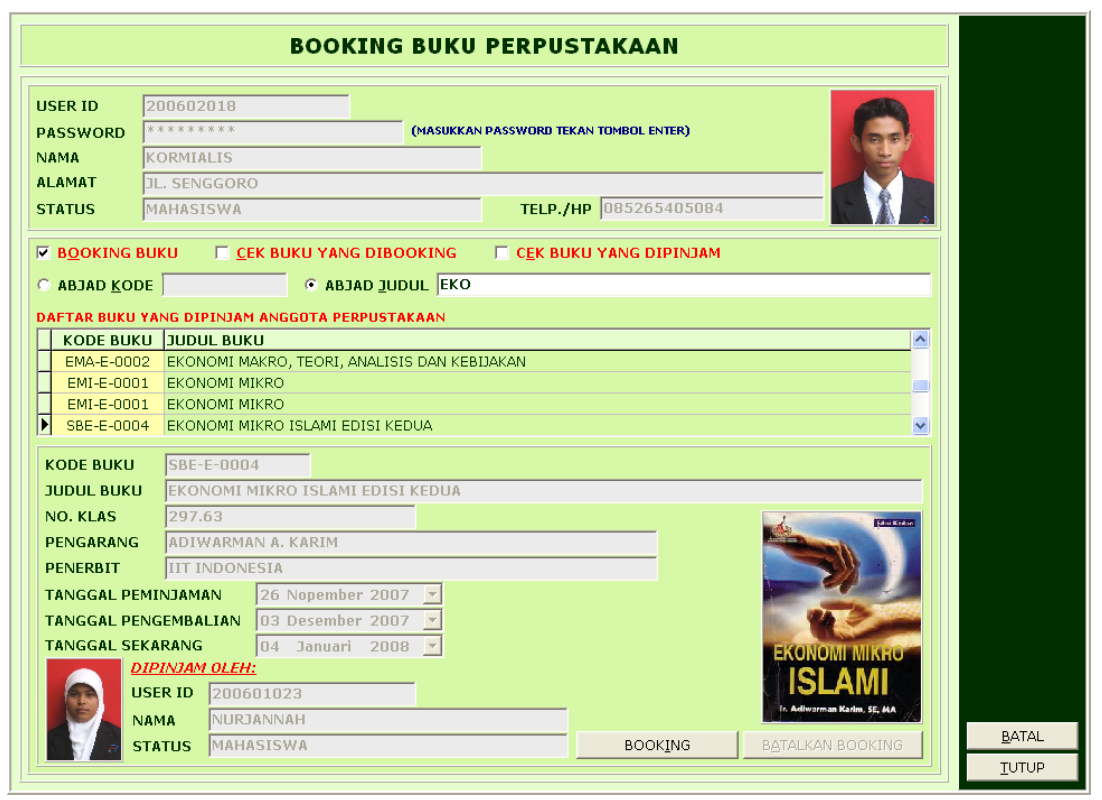

Gambar 10. Fitur Booking Buku

\section{Penelusuran/Pencarian}

Fitur ini diaktifkan melalui menu Pencarian yang berfungsi untuk melakukan pencarian buku, isi buku, skripsi, isi skripsi dan definisi/kamus. Untuk pencarian buku bisa dilakukan dengan beberapa pilihan sekaligus, misalnya mau mencari berdasarkan judul buku dan pengarang. Jadi seorang user bisa mencari buku dengan cara memasukkan kata kunci (keyword) yaitu pada item kode buku, judul buku, nomor klas, subjek, nama pengarang, penerbit, kota terbit. Untuk, bahasa, jenis buku dan tahun terbit harus di isi lengkap atau dipilih sesuai dengan pilihan. Sedangkan untuk pencarian abjad judul atau abjad kode hanya tinggal memasukkan huruf abjad sesuai dengan keinginan, setiap memasukkan abjad maka akan muncul hasil pencarian (Gambar 11). 
Sedangkan untuk pencarian skripsi dan isi skripsi serta definisi/kamus pada prinsipnya sama caranya dengan pencarian buku dan isi buku, hanya bahasa pengantar dan tampilannya saja yang sedikit berbeda (Gambar 12).

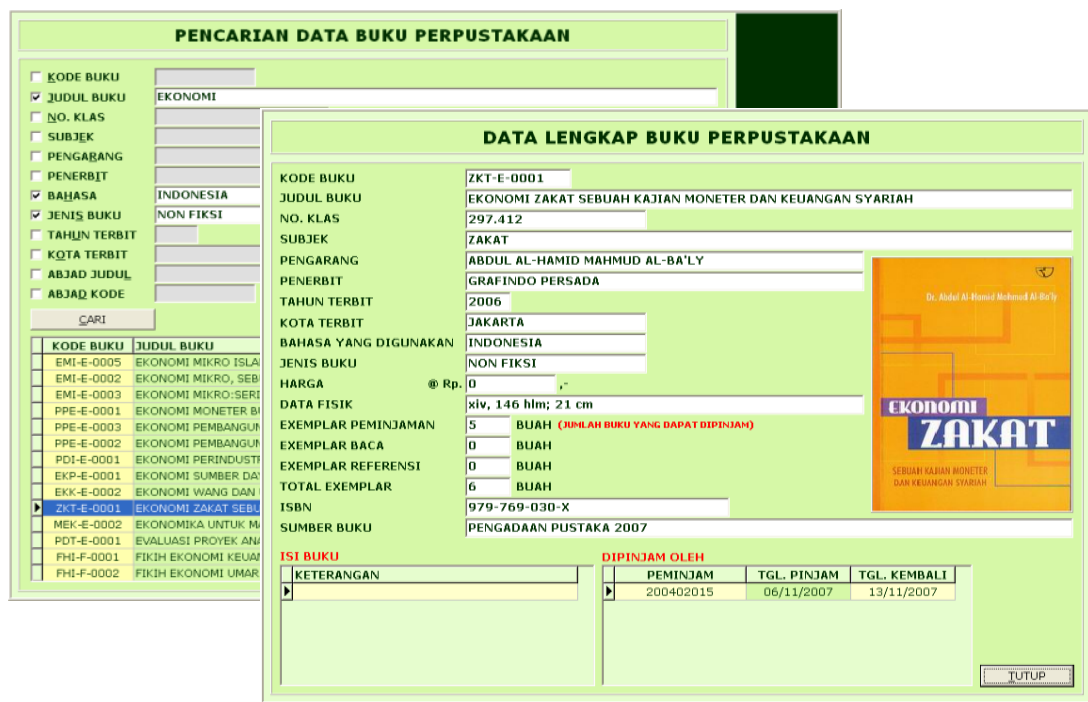

Gambar 11. Fitur Pencarian Buku

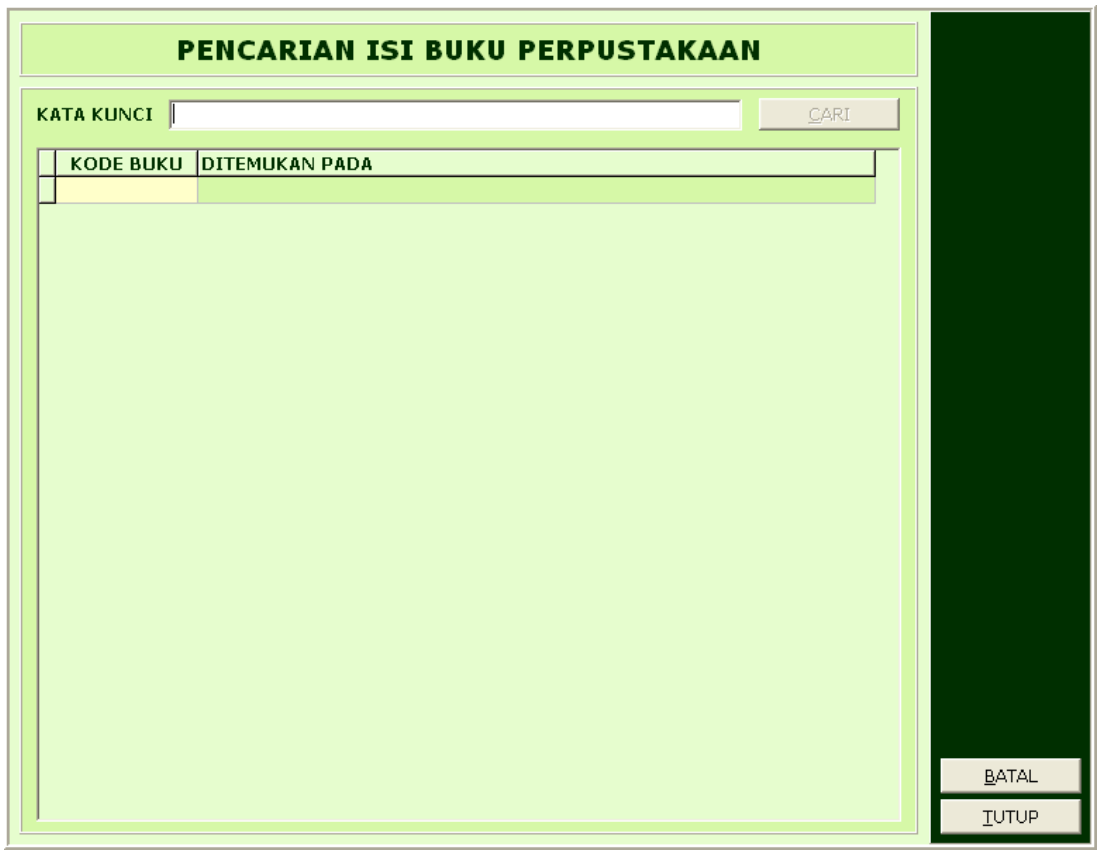

Gambar 12. Fitur Pencarian Isi Buku 


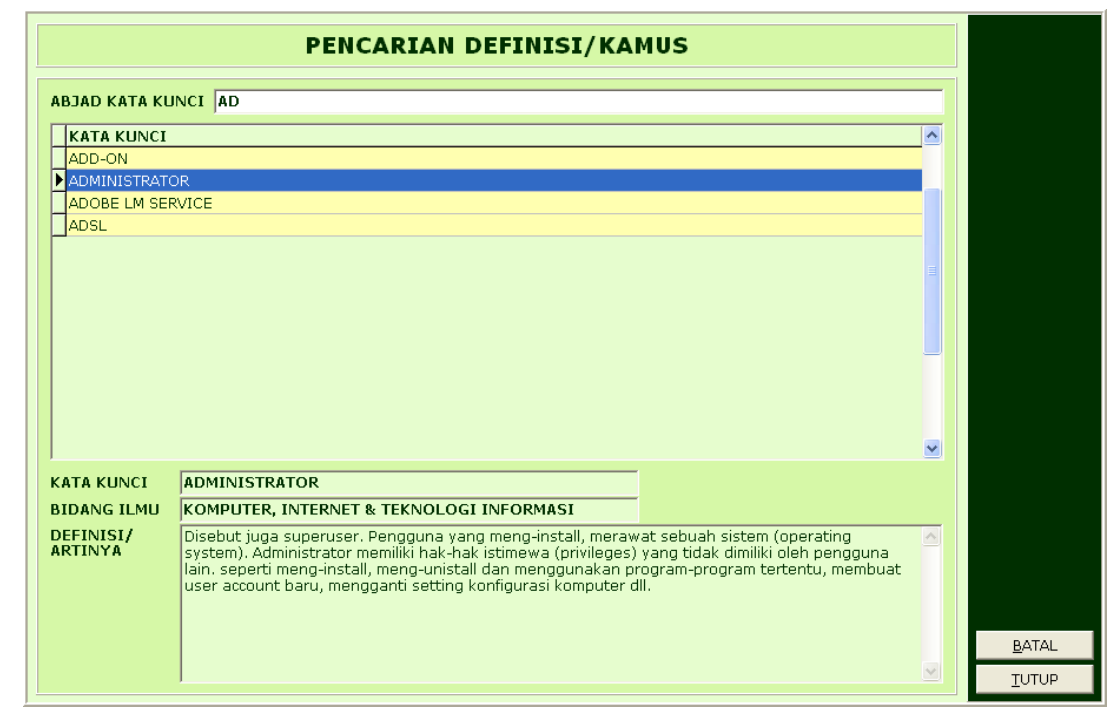

Gambar 13. Fitur Pencarian Definisi/Kamus

\section{Reporting dan Grafik}

Fitur ini merupakan laporan dari berbagai fitur yang terdapat pada sistem dalam bentuk tabel ataupun grafik. Fitur yang memiliki reporting dan grafik adalah user, buku, skripsi, transaksi (sirkulasi) dan pengunjung. Sedangkan reporting untuk data buku dan user ada yang berbentuk tabel dan detail pakai cover dan grafik seperti Gambar 14, Gambar 15 dan Gambar 16.

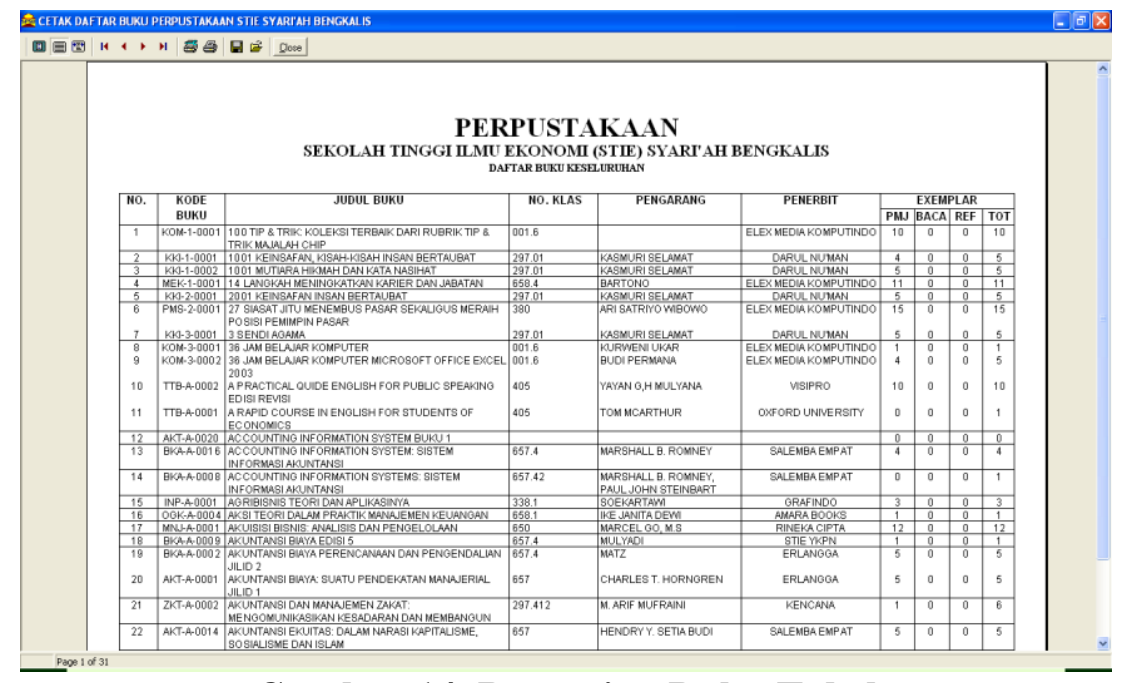

Gambar 14. Reporting Buku Tabel 


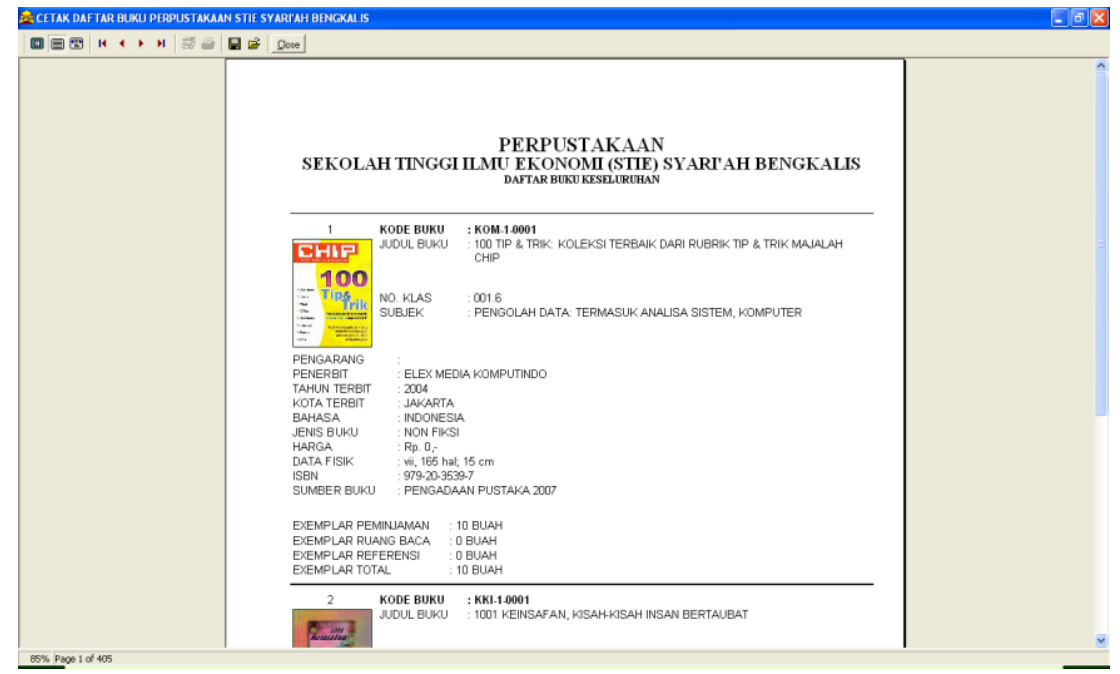

Gambar 15. Reporting Buku Detail

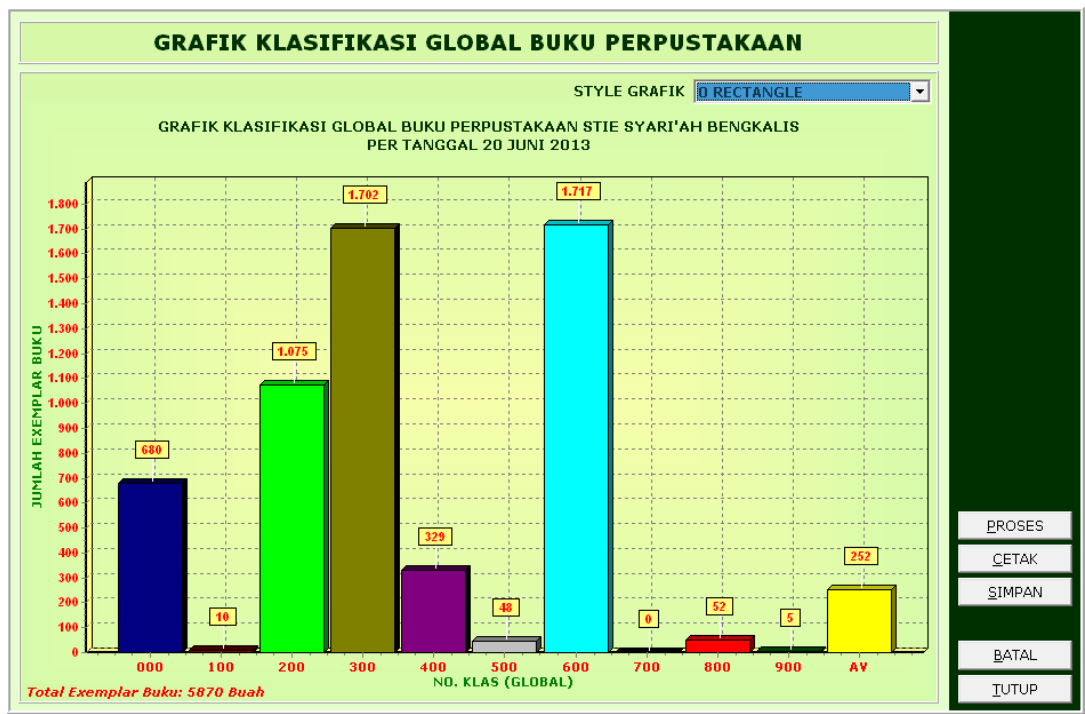

Gambar 16. Reporting Buku Dalam Bentuk Grafik

\section{Utility}

Fitur ini diaktifkan melalui menu "Utility" yang mempunyai banyak fungsi, mulai dari tukar password (Gambar 17), set lokasi komputer, set denda per hari (Gambar 18), set jumlah \& lama peminjaman buku (Gambar 19), database manager dan lain-lain yang diperuntukan untuk superuser. Sedangkan untuk fitur tukar password semua user mempunyai hak untuk mengaksesnya (menukar password), sehingga user mempunyai privasi sendiri untuk akses sistem. Jika user lupa password disini tidak disediakan fitur untuk mengingat password, jadi user yang bersangkutan harus melapor kepada pengelola perpustakaan. 


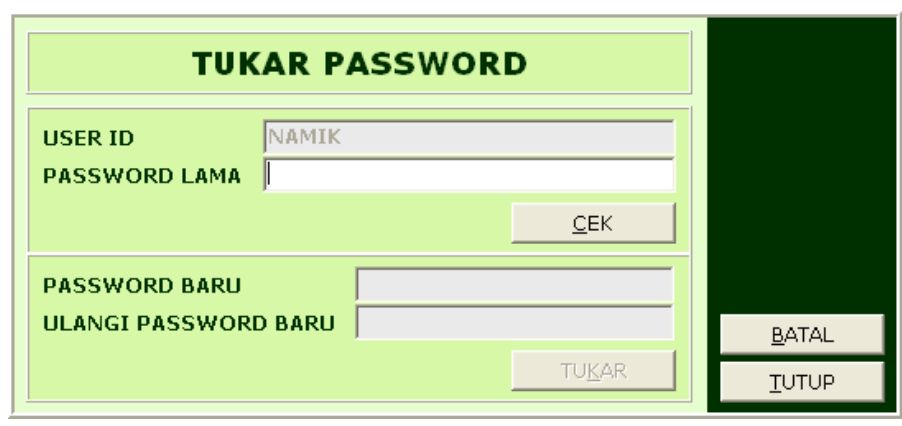

Gambar 17. Fitur Tukar Password

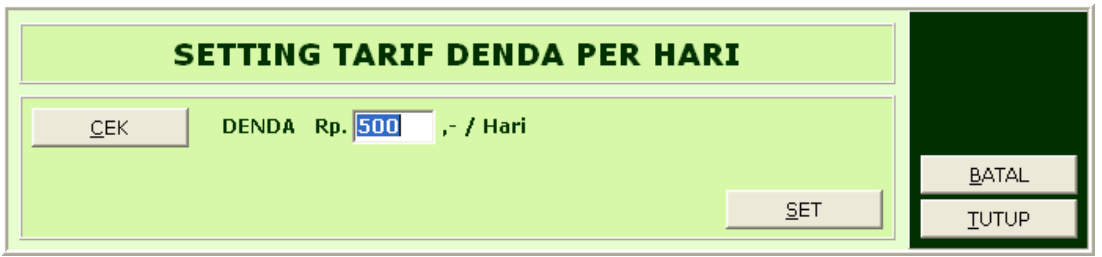

Gambar 18. Fitur Setting Tarif Denda Per Hari

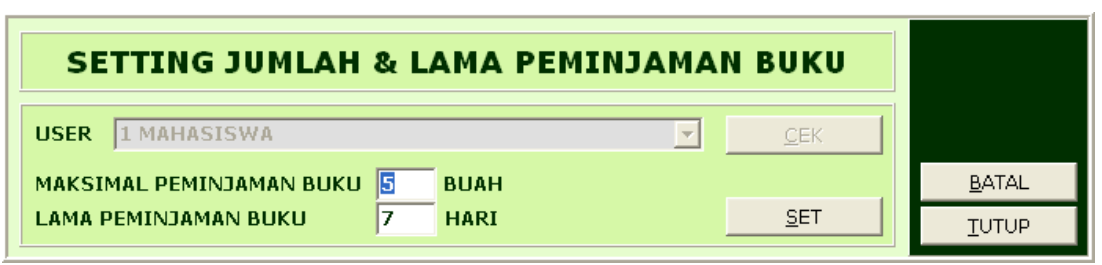

Gambar 19. Fitur Setting Jumlah \& Lama Peminjaman Buku

\section{PENUTUP}

Pada tulisan ini telah diuraikan tentang definisi perpustakaan digital, proyek-proyek perpustakaan digital, pengembangan perpustakaan digital dan hak cipta dokumen serta pemanfaatan teknologi informasi, khususnya dalam sistem pengolahan dokumen elektronik (digitalisasi) dan otomasi perpustakaan. Sehingga dapat ditarik kesimpulan yaitu perbedaan mendasar antara perpustakaan digital (Digital Library) dan sistem otomasi perpustakaan adalah tujuannya. Dimana perpustakaan digital (Digital Library) lebih berorientasi kepada koleksi-koleksi bahan pustaka yang sudah didigitalisasikan (file elektronik) untuk disharekan. Sedangkan sistem otomasi perpustakaan lebih cenderung kepada manajemen dan akses pengelolaan sistem perpustakaan, sehingga dapat meringankan beban pustakawan atau pengelola dari perpustakaan dan mempermudah pengguna perpustakaan. Perpustakaan STIE Syariah Bengkalis sendiri sudah melakukan perpaduan antara dua hal tersebut, dalam pengertian bahwa sistem otomasi perpustakaan disamping berorientasi kepada manajemen dan akses pengelolaan sistem perpustakaan, juga menyimpan koleksi dokumen yang telah didigitalisasikan (file elektronik) yang bisa disharekan atau diintegrasikan dengan menggunakan teknologi intranet, web dan internet. Walaupun Sistem Informasi dan Automasi Perpustakaan STIE Syariah sudah berfungsi dengan baik tapi manajemen perpustakaan belum sepenuhnya dapat mendigitalisasikan semua dokumen-dokumen atau data-data yang ada di perpustakaan mungkin dalam waktu yang bertahap dapat menyelesaikannya. Namun dengan adanya Sistem Informasi dan Automasi Perpustakaan (SIAP) STIE Syariah Bengkalis ini sangat membantu sekali dalam operasional Perpustakaan STIE Syariah Bengkalis. 


\section{DAFTAR PUSTAKA}

Bambang Setiarso, 2006, “Roadmap Perpustakaan Digital Iptek”, Ilmu Komputer.Com (IKC).

Connolly, T.M., and Begg C.E., 2002, "Database Systems: A Practical Approach to Design, Implementation, and Management ( $3^{\text {rd }}$ edition)", Boston, United States. Addison Wesley.

Nawa Kotaro, 1996, "Digital Library and Copyright”, IPJS Journal Vol. 37 No. 9 1996, Japan. (Japanese).

Romi Satria Wahono, 1998, "Digital Library: Chalenges and Roles Toward $21^{\text {th }}$ Century", Proceedings of Tekno '98 Symposium, Nagaoka, Japan.

Romi Satria Wahono, "Menengok Proyek Digital Library", http://elearning.unej.ac.id/courses/IKC20042/document/pdf01/romidl.pdf?cidReq=IKC20042. Diakses tanggal 20 Juni 2013.

Romi Satria Wahono, 2006, “Teknologi Informasi untuk Perpustakaan: Perpustakaan Digital dan Sistem Otomasi Perpustakaan”, Ilmu Komputer.Com (IKC).

Tabata Kouchi, 1996, “What is Digital Library”, IPSJ Journal Vol. 37 No. 9 1996, Japan, (Japanese).

Yudha Yudhanto, 2008, “Menggagas Perpustakaan Digital”, Ilmu Komputer.Com (IKC). 